\title{
Results of monitoring groundwater above the natural gas underground storage at Stenlille, Denmark
}

\author{
Troels Laier
}

Groundwater in the Stenlille area is regularly analysed for light hydrocarbons after a natural gas underground storage facility was established there in 1989. The monitoring is carried out by the Geological Survey of Denmark and Greenland and is part of the authorities' requirements for the environmental approval of the natural gas storage run by the state-owned Danish Oil and Gas company DONG A/S. Groundwater from observation wells and water wells in the area was analysed every month during the first year of operation and four times a year in the following years. More frequent analyses are undertaken on special occasions.

\section{Underground gas storage}

Two underground storage facilities were established in Denmark in order to buffer the supply of gas from the North Sea, one in salt caverns in Jylland, the other in a deep aquifer at a depth of $1500 \mathrm{~m}$ near Stenlille (Fig. 1). Natural gas underground storage is possible in deep sealed geological formations with good reservoir quality and covered by tight caprock. These conditions are met by an anticlinal structure near Stenlille with a vertical closure of $c .35 \mathrm{~m}$ covering an area of $14 \mathrm{~km}^{2}$. The Gassum Formation forms the reservoir where gas is stored by displacing formation water. The formation is of Late Triassic age and consits of cyclically interbedded sandstone and marine mudstone that were deposited as a result of changes in the depositional environment (Hamberg $\&$ Nielsen 2000). The overlying $300 \mathrm{~m}$ thick Lower Jurassic Fjerritslev Formation, which consists of claystone, serves as a caprock for the sandstone reservoir (Fig. 2). The total estimated storage capacity of the Stenlille structure equals three billion normal cubic metres, and due to reservoir heterogeneities, gas is stored in several separate zones (Fig. 1). The gas storage is operated by 14 wells for injection and withdrawal of gas and six wells used for observational purposes, most of them in the periphery of the structure.
Fig. 1. Map of the Stenlille area showing the location of water wells (blue), observation wells for shallow aquifers (green, inset map) and deep wells (red). The extent of the underground gas storage is indicated by coloured areas, where yellow and red show different gas zones.

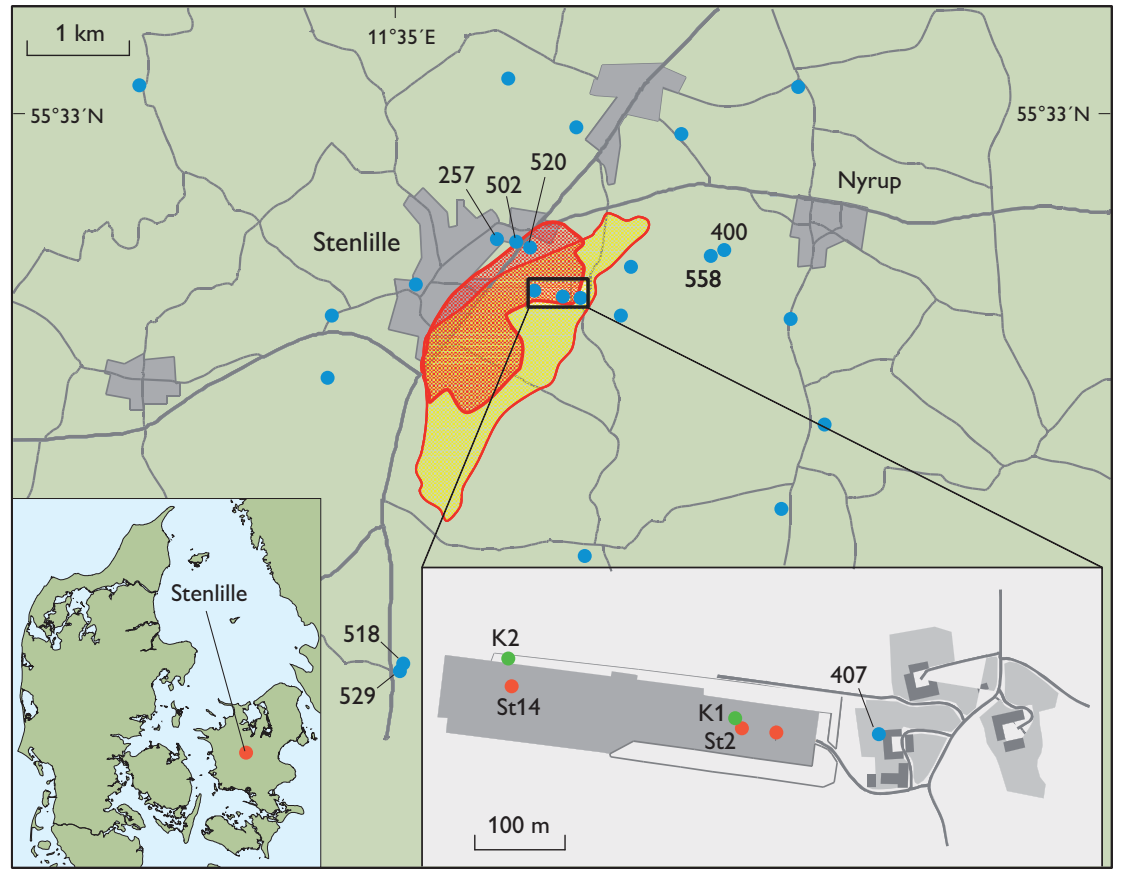




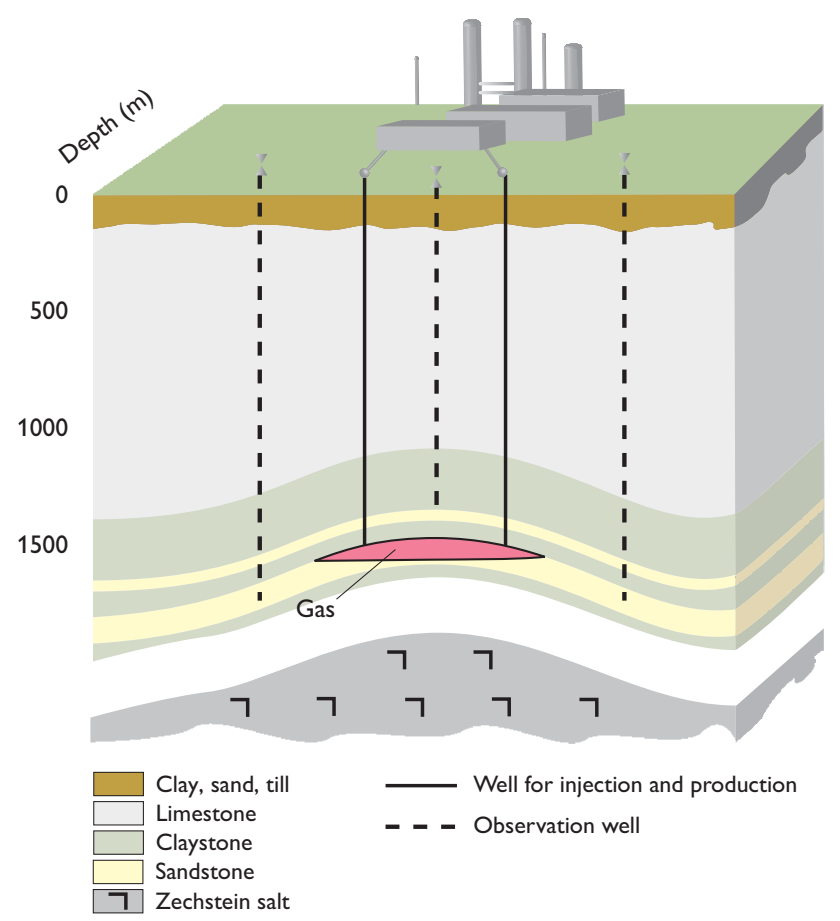

Fig. 2. Sketch of the natural gas underground storage facility at Stenlille. A Zechstein salt pillow is located below the surface. The development of the salt pillow has deformed the overlying beds into a dome. Sandstone: Gassum Formation sandstone (Late Triassic), claystone: Fjerritslev Formation (Early Jurassic).

\section{Baseline study}

As part of the pre-investigation of the Stenlille stucture, a baseline study was carried out in order to characterise the type and concentration of natural hydrocarbons present in the rocks within and above the future gas storage reservoir. Analyses of hundreds of drill cuttings from deep wells indicated no significant occurrence of hydrocarbons, although low concentrations of in situ generated hydrocarbons appeared to be present in the organic rich Fjerritslev Formation (Laier \& Øbro 2009). A very low concentration of methane $(30 \mathrm{mg} / \mathrm{l})$, possibly of microbial origin, was observed in the saline formation water of the Gassum Formation (Laier \& Øbro 2009).

\section{Bacterial methane in groundwater}

Methane is generally not analysed in groundwater unless its presence is suspected; therefore very few analyses existed prior to the baseline study. Groundwater from 21 water wells in the Stenlille area was sampled, and methane was found to occur in low concentrations $(0.01-0.49 \mathrm{mg} / \mathrm{l})$ in all of them except two (Laier 1989). No higher hydrocarbons were detected in any of the samples. Stable isotope analyses of nine of

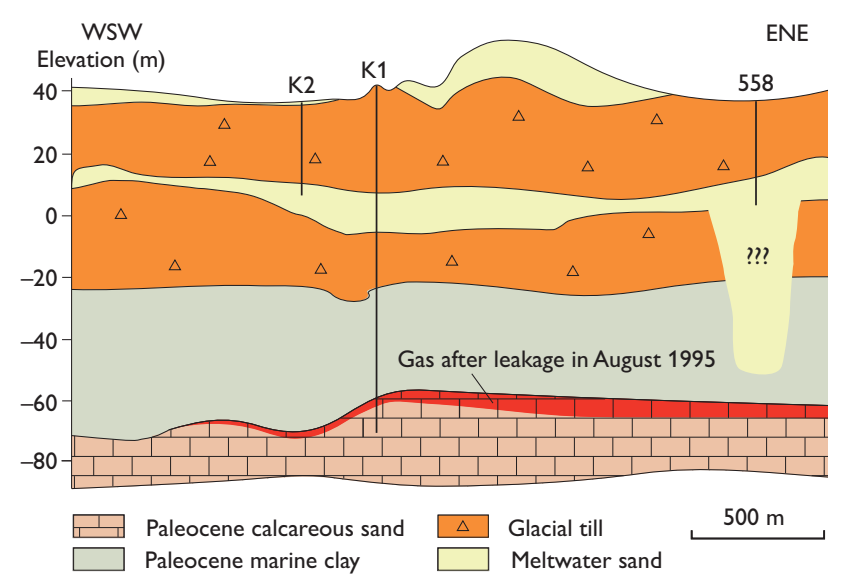

Fig. 3. Geological cross section of the upper layers of the Stenlille natural gas underground storage. The locations of wells K1, K2 and 558 are shown on Fig. 1. The red colour indicates the distribution of gas after the St14 leakage in August 1995 (for details see Laier 2010).

the samples showed that the methane was of bacterial origin $\left(\delta^{13} \mathrm{C}_{\mathrm{CH} 4}\right.$ : -90 to $-62 \%$; Laier 1989$)$. The bacterial methane most likely comes from peat layers in the area. Most water wells in the area draw water from glacial meltwater sand found at depths of $20-30 \mathrm{~m}$ and overlain and underlain by glacial till (Fig. 3).

Bacterial methane $\left(0.40 \mathrm{mg} / 1 ; \delta^{13} \mathrm{C}_{1}=-64.5 \%\right)$ was also found in groundwater from the shallow filter of the $\mathrm{K} 1 \mathrm{ob}-$ servation well located adjacent to the first injection well (St2; Fig. 1). The methane concentration in the brackish water from the deep filter (Fig. 3) was too low $(0.02 \mathrm{mg} / \mathrm{l})$ to permit analysis of its carbon isotope ratio.

\section{Natural gas storage}

Storage of natural gas from the Danish part of the North Sea began in July 1989. The gas is dominated by methane (91\%) with a little ethane (5.5\%) and propane (2.0\%). The average $\delta^{13} \mathrm{C}_{\mathrm{CH} 4}$ value of methane is $-46.6 \%$. The composition of the natural gas stored in the Stenlille structure is markedly different from that of the gas dissolved in shallow groundwater (Fig. 4). This makes it fairly easy to distinguish between the two types of gas and identify even minor leaks from the deep gas storage reservoir at the near surface.

\section{Groundwater methane}

A fairly large variation in the concentration of methane from 0.4 to $3.7 \mathrm{mg} / \mathrm{l}$ was observed in water samples from a shallow filter of the K1 observation well in the early 1990s, but not in samples from a deeper filter, which had very low values $(0.02 \mathrm{mg} / \mathrm{l}$; Fig. 5). If the variation in methane concentra- 


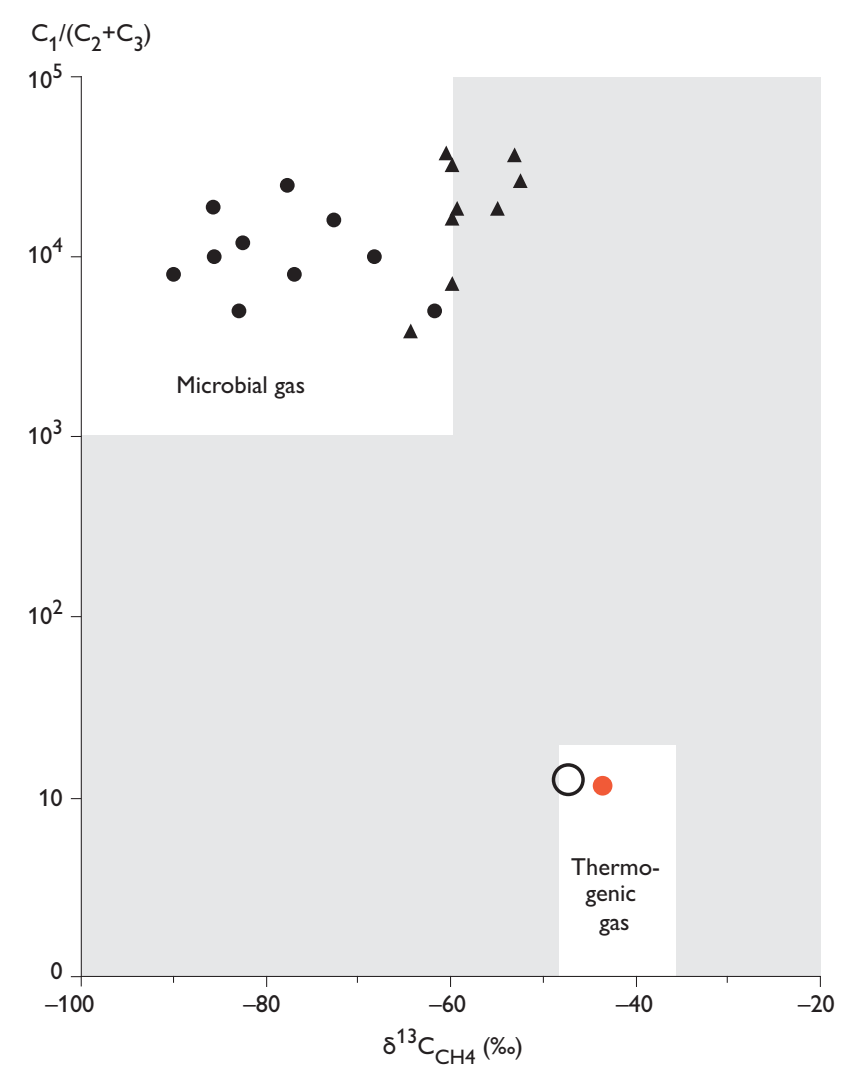

A Dissolved gas in the upper aquifer of the $\mathrm{K} 1$ observation well

- Dissolved gas in the shallow aquifers

Natural gas from the Danish North Sea

Dissolved gas in the lower aquifer of K1 from the gas leakage in 1995

Fig. 4. Classification diagram showing the chemical and isotopic composition of natural gas from the Danish North Sea and dissolved gas in shallow aquifers. The $\mathrm{C}_{1} /\left(\mathrm{C}_{2}+\mathrm{C}_{3}\right)$ ratio for the dissolved gas represents a minimum value as both ethane and propane were below detection limit for all dissolved gases. The white areas are typical of thermogenic and microbial gas and the grey area represents either mixtures of these gas types or gas of unknown origin. $\mathrm{C}_{1}$ : methane concentration, $\mathrm{C}_{2}$ : ethane concentration, $\mathrm{C}_{3}$ : propane concentration.

tion was due to a leakage around the nearby St2 well (Fig. 1), the opposite might be expected with an increase in methane at the deeper level first. In order to deduce the origin of the methane, isotope analyses were regularly performed during the first year of sampling. The isotope ratio of the methane $\left(\delta^{13} \mathrm{C}_{\mathrm{CH} 4}:-62\right.$ to $-52 \%$ ) together with a lack of higher hydrocarbons indicate that the methane was bacterial in origin (Fig. 4), though its source remains unknown. Since the methane concentration was highest during the first years after drilling the K1 well, one may speculate whether hydrogen generated by anaerobic corrosion of iron filings from drilling may have led to methane formation as suggested by Daniels et al. (1987). Groundwater methane concentration in water from the Stenlille waterworks and from private water wells remained at the low levels measured prior to the storage of natural gas (Fig. 6).

\section{Minor gas leakage}

In September 1995, gas bubbles were observed at the terrain surface near the newly drilled St14 injection well (Fig. 1), and a sample of the gas was immediately collected and analysed. Its chemical and isotopic composition was similar to that of the gas being stored (Fig. 4), so there was little doubt that gas leaked from the new well. The leak was due to technical problems during gas injection (Laier \& Øbro 2009) and was quickly stopped, but an estimated $5000 \mathrm{~m}^{3}$ of gas was lost to geological formations above the reservoir cap rock.

A week after the leak was observed at the surface, a significant increase in the dissolved gas concentration was measured in the deep filter of the K1 well, located $250 \mathrm{~m}$ from the St14 well. This gas had almost the same composition as the reservoir gas (Fig. 4). No free gas was observed during collection of water from this level, so it was concluded that all the gas was dissolved at this time. However, for the gas to migrate from St14 to K1 during a week, a free gas phase

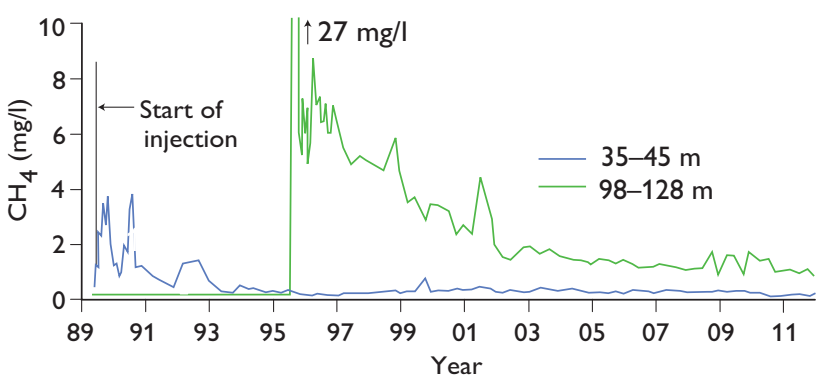

Fig 5. Methane concentration in groundwater from the K1 observation well. The sudden increase in dissolved methane was noted one week after the gas leakage at St14.
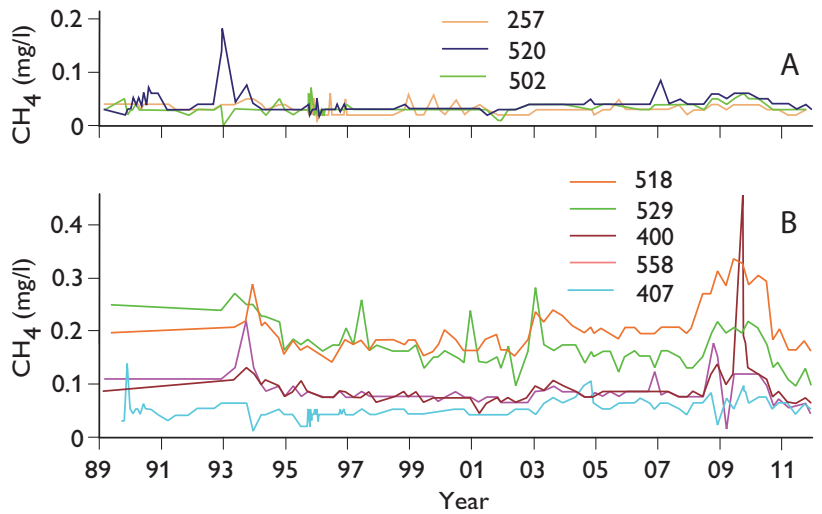

Fig. 6. Methane concentration in groundwater from wells supplying the Stenlille waterworks (A) and from private wells (B). 
must have existed at some point, although free gas was never observed in the samples from any of the wells. The concentration of dissolved gas has decreased since the gas leakage occurred and is presently below $1 \mathrm{mg} / \mathrm{l}$, and its composition has hardly changed.

\section{Traces of natural gas in a water well near Nyrup}

The regular groundwater survey revealed a significant increase in methane in October 2009, from 0.1 to over 0.4 $\mathrm{mg} / \mathrm{l}$, in water well 558 south-west of Nyrup (Figs 1, 6B). Traces of ethane and propane were also observed, indicating the presence of natural gas in low concentrations. An immediate follow-up investigation indicated a high proportion of old groundwater in the well due to a low pumping rate. When the normal pumping rate for the well was reestablished, groundwater methane dropped below $0.1 \mathrm{mg} / \mathrm{l}$ and the higher hydrocarbons ethane and propane could no longer be detected. It was concluded that minor amounts of natural gas from the leak in 1995 had migrated into the Paleocene calcareous sand below Paleocene marine clay of low permeability and reached the water well near Nyrup (Fig. 3; Laier 2010). A buried valley at Nyrup may have allowed gas to migrate to shallower depths where it gradually dissolved in groundwater (Jørgensen \& Sandersen 2009). The very low pumping rate in well 558 resulted in less infiltration of younger groundwater, which enabled the detection of natural gas in older groundwater (Laier 2010).

\section{Conclusions}

No leakage from the natural gas underground storage has occurred through the natural (geological) barriers. Regular analyses of dissolved hydrocarbons in shallow groundwater only showed the presence of bacterial methane, which was also present prior to the storage of natural gas. The traces of natural gas observed for a short period in one of the water wells in 2009 could be related to a minor leak from a newly drilled injection well in August 1995.

\section{References}

Daniels, L., Belay, N., Rajagopal, B.S. \& Weimer, P.J. 1987: Bacterial methanogenesis and growth from $\mathrm{CO}_{2}$ with elemental iron as the sole source of electrons. Science 237, 509-511.

Hamberg, L. \& Nielsen, L.H. 2000: Shingled, sharp-based shoreface sandstones: depositional response to stepwise forced regression in a shallow basin, Upper Triassic Gassum Formation, Denmark. In: Hunt, D. \& Gawthorpe, R.L. (eds): Sedimentary reponses to forced regressions. Geological Society Special Publications (London) 172, 69-89.

Jørgensen, F. \& Sandersen, P. 2009: Kortlægning af begravede dale i Danmark. Opdatering 2007-2009, 374 pp. Copenhagen: Geological Survey of Denmark and Greenland. http://www.begravededale.dk/ PDF_2009/Rapport_Begravede_dale_2009_137mb.pdf

Laier, T. 1989: Stenlille Gas Storage - study of naturally occurring hydrocarbon gases before injection. DGU Service Report 15, 53 pp. Copenhagen: Geological Survey of Denmark.

Laier, T. 2010: Spor af naturgas i Nyrup vandværksboring oktober 2009. Danmarks og Grønlands Geologiske Undersøgelse Rapport 2010/1, 30 pp.

Laier, T. \& Øbro, H. 2009: Environmental and safety monitoring of the underground gas storage facility at Stenlille, Denmark. In: Evans, D.J \& Chadwick, R.A. (eds): Underground gas storage: worldwide experiences and future development in the UK and Europe. Geological Society Special Publications (London) 313, 81-92.

\footnotetext{
Author's address

Geological Survey of Denmark and Greenland, Øster Voldgade 10, DK-1350 Copenhagen K, Denmark. E-mail: tl@geus.dk
} 